\title{
Introduksi Bahan Bakar Wood Pellet pada IKM Makanan
}

\author{
Introduction Wood Pellet Fuel in Small and Medium Enterprises
}

Syamsudin
Muzakar Isa
Siti Fatimah Nurhayati
Siti Zulaekah
Aflit Nuryulia Praswati*
Department of Management,
Universitas Muhammadiyah
Surakarta, Surakarta, Central Java,
Indonesia
*email: aflit.n.praswati@ums.ac.id
Kata Kunci
Bahan Bakar
IKM
Wood pellet
Keywords:
Fuel accepted: November 2019
Published: December 2019
Wood pellets

\begin{abstract}
Abstrak
Industri Kecil Menengah (IKM) berperan penting dalam pertumbuhan ekonomi daerah Kabupaten Sragen. Upaya pemberdayaan IKM perlu terus dilakukan, salah satunya dengan menjaga ketersediaan bahan bakar. IKM Kecamatan Kedawung saat ini menggunakan bahan bakar kayu namun terhambat oleh kualitas kayu bakar yang kurang kering. IKM nata de coco sempat beralih menggunakan gas elpiji namun sering kesulitan mendapatkannya, jika menemukannyapun dengan harga yang tinggi. Wood pellet adalah salah satu alternatif sumber bahan bakar yang dapat digunakan IKM di Kabupaten Sragen. Kabupaten Sragen telah memiliki produsen wood pellet yang terletak di Kecamatan Kalijambe. Solusi yang ditawarkan pada IKM adalah energi alternatif biomassa wood pellet. Program Kemitraan Masyarakat (PKM) yang akan dilakukan yaitu pada bidang produksi berupa introduksi energi biomassa wood pellet dan bidang manajemen berupa perhitungan kelayakan pengggunaan wood pellet bagi pengembangan usaha. Rencana kegiatan PKM ini antara lain pelatihan dan sosialisasi energi biomassa wood pellet, introduksi kompor berbahan bakar wood pellet, pelatihan penggunaan kompor berbahan bakar wood pellet. Target luaran kegiatan PKM ini yaitu IKM Kabupaten Sragen mendapatkan pengetahuan dan keterampilan menggunakan energi alternatif biomassa wood pellet sebagai bahan bakar.
\end{abstract}

\begin{abstract}
Small and Medium Enterprises (IKM) play an important role in the economic growth of Sragen Regency. Efforts to empower SMEs need to be continued, one of which is by maintaining the availability of fuel. The IKM of Kedawung District currently uses wood fuel but is hampered by the quality of firewood that is less dry. Nata de coco IKM had switched to using LPG, but it was often difficult to get it, if they found it at a high price. Wood pellets are an alternative fuel source that can be used by SMIs in Sragen Regency. Sragen Regency already has wood pellet producers located in Kalijambe District. The solution offered at IKM is alternative energy biomass wood pellets. The Community Partnership Program (PKM) to be carried out is in the form of production in the form of introduction of wood pellet biomass energy and management in the form of calculating the feasibility of using wood pellets for business development. The PKM activity plan includes training and socialization of wood pellet biomass energy, introduction of wood pellet stoves, training on the use of wood pellet stoves. The target of this PKM activity output is the IKM of Sragen Regency to get knowledge and skills to use alternative energy biomass wood pellets as fuel.
\end{abstract}

\section{PENDAHULUAN}

Mitra Program Kemitraan Masyarakat (PKM)

Kabupaten Sragen yaitu Industri Kecil Menengah (IKM)

nata de coco. Usaha nata de coco merupakan salah satu usaha di industri makanan olahan di Kabupaten Sragen.

Biaya bahan bakar yang dikeluarkan IKM mencapai Rp.

1.500.000,- per bulan. Air kelapa sebagai bahan baku nata de coco diperoleh dari daerah Sragen dan Ngawi. 
Proses perebusan air kelapa menggunakan bahan bakar kayu (Ariyanti et al., 2014). Kayu bakar yang digunakan adalah limbah mebel kayu dari daerah Karanganyar. Pelaku usaha setiap hari mengeluarkan biaya pembelian kayu bakar sebesar Rp. 120.000,-. Dulu pengelola IKM nata de coco pernah menggunakan bahan bakar gas elpiji. Pemakaian rata-rata gas elpiji sebanyak 6 tabung ukuran $3 \mathrm{~kg}$ setiap harinya. Satu tabung gas elpiij ukuran $3 \mathrm{~kg}$ bisa untuk merebus 120 L air kelapa. Namun karena kelangkaan gas elpiji dan harganya yang tinggi sebesar Rp. 18.000,- membuat pengelola IKM lebih banyak menggunakan bahan bakar kayu. Hasil rebusan air kelapa tersebut kemudian didiamkan selama 8 hari hingga siap panen (Nurdyansyah \& Widyastuti, 2017).

Permasalahan yang dihadapi adalah ketidakpastian jumlah persedian bahan bakar. Proses produksi pada tahap perebusan air kelapa pada IKM nata de coco, membutuhkan biaya bahan bakar kayu sebesar Rp. 120.000,- sedangkan jika menggunakan gas elpiji, dalam sehari IKM nata de coco membutuhkan 6 tabung gas elpiji bersubsidi ukuran $3 \mathrm{~kg}$. Jumlah kebutuhan yang tinggi namun sering terkendala kelangkaan dan harga (Syamsudin et al., 2019).

Permasalahan prioritas yang akan diatasi melalui Program Kemitraan Masyarakat ini adalah bidang produksi. Kesulitan untuk mendapatkan bahan bakar yang tepat dengan harga yang efisien selalu menjadi permasalahan utama bagi mitra IKM nata de coco. Penggunaan kayu bakar masih terkendala dengan ketersediaan, kualitas kayu bakar yang kurang bagus mempengaruhi waktu produksi. Penggunaan gas elpiji bersubsidi kurang tepat jika digunakan untuk produksi skala IKM. Kelangkaan persediaan gas elpiji dan harga yang mahal membuat biaya produksi IKM semakin tinggi (Iriyanto et al., 2015).

Wood pellet diyakini dapat menjadi bahan bakar alternatif yang dapat digunakan oleh IKM olahan makanan.
Energi terbaru yang sedang didengungkan dapat menggantikan gas elpiji dan kayu bakar adalah wood pellet (Arsad, 2014). Namun IKM belum sepenuhnya mengetahui kelayakan dan cara penggunaan wood pellet. Kegiatan Pengabdian ini bertujuan untuk memperkenalkan Penggunaan wood pellet sebagai bahan bakar alternatif bagi IKM nata de coco di Kabupaten Sragen.

\section{METODOLOGI}

Pelaksanaan Program Kemitraan Masyarakat pada IKM Nata de coco Kabupaten Sragen melalui beberapa tahapan yaitu sosialisasi dan koordinasi, pelatihan dan sosialisasi energi biomassa wood pellet pada keamanan olahan pangan, dan diakhir dengan kegiatan pelatihan penggunaan kompor berbahan bakar wood pellet.

\section{HASIL DAN PEMBAHASAN}

Tim pelaksana PKM melakukan sosialisasi tentang program-program penyelesaian masalah prioritas yang telah disepakati dengan mitra PKM. Koordinasi waktu dan tempat pelaksanaan program. Mitra akan diberi penjelasan mengenai:

1. Gambaran Umum wood pellet. Ketergantungan akan bahan bakar sangat besar bagi setiap industri, kekhawatiran akan langkanya bahan bakar ini membuat masyarakat berfikir untuk membuat teknologi ramah lingkungan dan dapat diperbaharui. Salah satunya adalah dengan cara mengembangkan energi alternatif wood pellet yaitu energi yang dikembangkan dari limbah hasil hutan yang berasal dari limbah industri penggergajian, limbah tebangan, dan limbah industri kayu lainnya (Arhamsyah, 2010).

Beberapa negara di dunia telah mengambil keputusan penggunaan biomassa wood pellet sebagai energi bahan bakar. Sebagai contoh pada tahun 2009 
negara Swedia adalah negara Eropa pertama yang menggunakan lebih banyak energi biomassa. Swedia juga telah menciptakan lapangan pekerjaan dalam pengolahan limbah hutan lokal menjadi wood pellet yang produktif (Sidabutar, 2018).

2. Salah satu energi alternatif untuk memenuhi kebutuhan bahan bakar adalah penggunaan wood pellet. Wood pellet merupakan bahan bakar alternatif yang terbuat dari serbuk kayu atau grajen. Bahan baku wood pellet berupa limbah industri penggergajian, limbah tebangan, dan limbah industri kayu lainnya, bahan baku ini memiliki kadar ligan yang tinggi sebagai zat perekat alami (Sylviani \& Suryandari, 2013). Dengan perekat dan proses pengepresan menggunakan tekanan tinggi akan dihasilkan wood pellet berukuran diameter 6-10 $\mathrm{mm}$ dan panjang 10-30 mm, kepadatan rata-rata 650 $\mathrm{kg} / \mathrm{m}^{3}$ atau $1,5 \mathrm{~m}^{3} /$ ton. Limbah tanaman yang sering digunakan sebagai wood pellet berasal dari kayu seperti Albasia, Sengon (Falcataria mollucana), Kaliandra (Caliandra calothyrsus), mahoni, dan jati.

3. Proses pembuatan wood pellet dapat dilakukan dengan dua cara, yaitu proses kering dan basah. Proses kering yaitu dengan menggunakan bahan baku dikeringkan sampai kadar air maksimal 10\% selanjutnya dipres dengan tekanan tinggi dan dipanaskan pada suhu sekitar $120-180^{\circ} \mathrm{C}$. Sedangkan untuk proses basah menggunakan bahan baku dengan kadar air tinggi, ditambah tepung kanji sebagai perekat dan air kemudian dipres dengan tekanan tinggi, setelah itu baru dikeringkan (Hendra, 2012).

4. Tampilan wood pellet berupa buliran-buliran halus dengan sedikit retakan dan berkilau seperti warna coklat crayon serta dapat mudah terbakar dengan nyala api yang bagus. Wood pellet dapat digunakan sebagai bahan bakar pembakaran boiler, pemasakan dan penghangat ruangan. Saat ini cukup banyak industri rumahan hingga industri besar yang sudah beralih dari bahan bakar sebelumnya menuju wood pellet dikarenakan harga bahan bakar seperti kayu bakar, gas, oli bekas, dan batubara relatif lebih mahal dan limbah pembakarannya tentunya lebih sulit ditangani dari pada wood pellet (Sylviani \& Suryandari, 2013).

5. Keunggulan wood pellet sebagai sumber energi adalah bila dibandingkan dengan bahan bakar lainnya, wood pellet memiliki banyak kelebihan, yaitu memiliki emisi $\mathrm{CO}_{2} 10$ kali lebih rendah dari batu bara dan minyak serta 8 kali lebih rendah dari penggunaan gas, kadar air yang konstan, praktis dalam hal penggunaan dan penyimpanan, nilai kalori 4,7 $\mathrm{KWh} / \mathrm{kg}$ atau 19,6 GJ/od mg yang hampir sama dengan batubara pada jumlah yang sama, mudah dinyalakan, kadar abu yang rendah 0,5\%, dan asap lebih rendah dari penggunaan kayu bakar lainnya (Hieu \& Rasovska, 2017). Secara garis besar bahwa penggunaan wood pellet memiliki keunggulan dibandingkan dengan bahan bakar fosil, antara lain dapat diperbarui (renewable), efisien karena biaya lebih rendah, bersih, lebih ekonomis, mudah penggunaannya baik untuk memasak maupun untuk pembangkit listrik dan ramah lingkungan karena kadar karbon yang dihasilkan lebih rendah (Sylviani et al., 2013).

Dengan berbagai keunggulan tersebut, wood pellet telah menjadi sumber energi alternative terbarukan. Wood pellet dapat pula digunakan sebagai pembangkit listrik. Di negara Amerika dan Eropa wood pellet dibakar dengan sistem gasifikasi yang menghasilkan panas untuk memanaskan boiler. Uap panas yang dihasilkan oleh boiler inilah yang digunakan untuk menggerakkan turbin penghasil listrik (Sidabutar, 2018). 
6. Nilai ekonomi wood pellet. Produksi wood pellet di Indonesia pada tahun 2007 mencapai 40.000 ton, sementara produksi wood pellet dunia telah mencapai 10 juta ton. Produksi wood pellet tersebut belum mampu memenuhi kebutuhan wood pellet dunia sebesar 12.700.000 ton pada tahun 2010. Di Asia, wood pellet banyak di konsumsi oleh China, Korea Selatan dan Jepang. Terkait hal tersebut, Korea Selatan bekerjasama dengan Indonesia (Perhutani) telah membangun industri pengolahan wood pellet di Wonosobo, Jawa Tengah menggunakan sisa kayu Kaliandra dan Sengon dengan produksi awal 5.000 ton/bulan. Saat ini prouduksi wood pellet telah meningkat hingga 18.000 ton/tahun dengan bahan baku dipenuhi dari areal Perhutani seluas 30.000 ha Harga wood pellet saat ini sekitar Rp. 1.400.000,sampai 2.500.000,-/ton.

7. Peluang pengembangan wood pellet di Jawa Tengah juga ditangkap oleh pengusaha kayu di Kabupaten Sragen yaitu UD Karunia Jati yang berada di Desa Banaran Kalijambe, berdiri sejak tahun 2015. Berawal dari melimpahnya serbuk graji dari limbah kayu untuk mebel yang ada di Bandengan Wood Kalijambe yang belum diolah, UD Karunia Jati mengolah menjadi wood pellet dengan nilai investasi Rp. 2.500.000.000,-. Potensi produksi wood pellet dinyatakan layak ekspor ke negara Eropa dimana harga wood pellet cenderung tinggi (Simangunsong et al., 2017).

Wood pellet yang diproduksi berasal dari limbah kayu serbuk gaji atau grajen yang diambil dari pengrajin mebel di daerah Kalijambe. Jenis limbah kayu yang dipakai adalah kayu sengon, albasia, mahoni dan jati dari pengusaha mebel seperti Bandengan Wood. Pengolahan limbah serbuk graji menggunakan mesin berkapasitas besar yang diimpor langsung dari jerman, dengan kapasitas produksi wood pellet mencapai 8-10 ton/hari atau sekitar 200-240 ton/bulan dengan harga jual Rp. 2.000,- per Kg. Penjualan wood pellet di kemas dalam karung dengan berat $40 \mathrm{~kg}$ dengan harga jual Rp. 80.000,-/ / karung. Beberapa industri kecil menengah di Kabupaten Sragen dan sekitarnya yang sudah menggunakan wood pellet antara lain industri tahu sari, pelayuan teh, garam, pupuk organik, dan lainnya. Kebutuhan wood pellet untuk industri tahu sari di Kabupaten Klaten mencapai 45 ton/bulan. Sedangkan untuk pabrik pupuk organik di Kabupaten Klaten menggunakan wood pellet sebagai pengganti bahan bakar yang semula menggunakan oli bekas. Pemakaian wood pellet untuk produksi pupuk mencapai $200 \mathrm{~kg} / \mathrm{hari}$. Selain untuk mensuplai bahan bakar ke industri tersebut, wood pellet ini juga untuk mensuplai PTPN VIII dengan rata-rata 100 ton/bulan.

Ketersediaan bahan baku limbah serbuk graji yang berlimpah dan wood pellet siap pakai memberi peluang bagi IKM di Kabupaten Sragen untuk mulai beralih ke bahan bakar wood pellet. Dorongan kepada masyarakat dan pelaku industri agar turut menggunakan wood pellet perlu terus digaungkan agar proses transformasi ini berhasil. Hal ini akan mengurangi ketergantungan IKM terhadap bahan bakar fosil yang semakin lama semakin menipis cadangannya, dan berganti kepada sumber energi terbarukan yang ramah lingkungan.

Kegiatan introduksi teknologi mesin ini untuk mendukung IKM dalam menerapkan penggunaan wood pellet sebagai bahan bakar alternatif. Potensi limbah kayu gergajian sebagai bahan bakar biomassa terbarukan yang cukup untuk memasok bahan baku pelet kayu (Sylviani \& Suryandari, 2013). Hal ini membuat keyakinan bahwa persediaan wood pellet akan terjaga selama ada limbah gergaji kayu yang melimpah. Kelayakan penggunaan wood pellet secara ekonomi bagi 
industri kecil telah diteliti dan dinyatakan layak untuk dijadikan alternatif bahan bakar pengganti gas elpiji dan kayu bakar (Syamsudin et al., 2019).

Teknologi yang akan diterapkan pada IKM adalah burner wood pellet. Burner wood pellet adalah alat pemanas yang menggunakan bahan bakar wood pellet. Alat ini digunakan sebagai media pemanas tungku-tungku di sektor industri pengolahan pangan. Penerapan teknologi mesin pemanas berbahan bakar wood pellet ini dimodifikasi sesuai kebutuhan mitra. Burner wood pellet dilengkapi dengan satu set alat penggorengan bagi mitra aneka pangan dan satu set alat perebusan air kelapa bagi mitra nata de coco Kabupaten Sragen (Hendra, 2012).

Para IKM sebelumnya mendapatkan sosialisasi mengenai penggunaan energi biomassa wood pellet menggunakan tungku sederhana berbahan baku kayu bakar. Bahan bakar kayu ini memerlukan ruang penyimpanan yang luas. Kualitas kayu yang tidak sama (kering dan basah) memerlukan upaya pemeliharaan tertentu agar tetap dalam keadaan kering sempurna sehingga proses pemasakan lebih cepat dan maksimal. Visualisasi kompor tungku kayu bakar yang biasa digunakan sebelumnya dapat dilihat pada Gambar 1 .

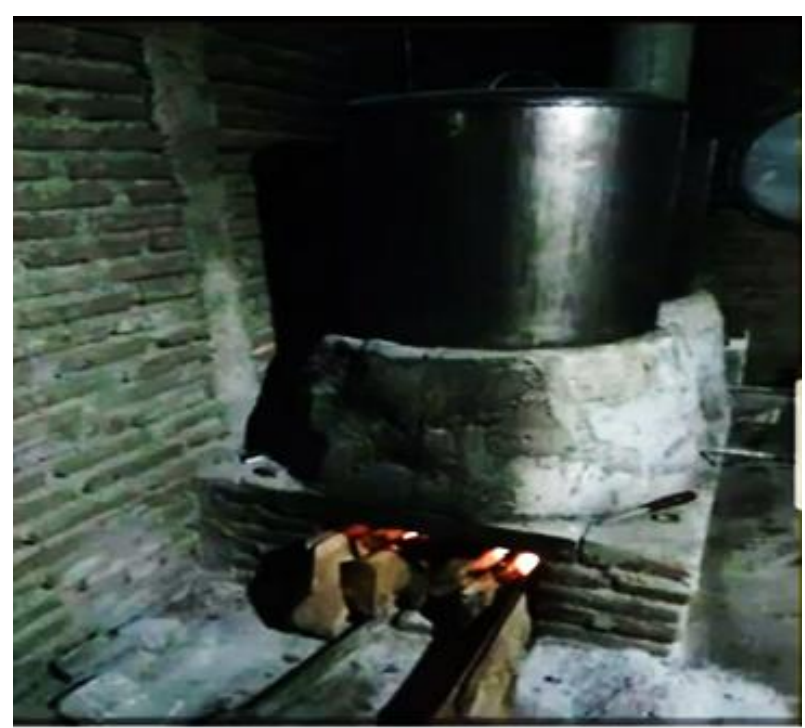

Gambar 1. Kompor tungku berbahan bakar kayu
Tim pengusul dari Universitas Muhammadiyah Surakarta (UMS) bekerjasama dengan Ristekdikti, Pemerintah Kabupaten Sragen dan pebisnis wood pellet memberikan pelatihan mengenai kompor wood pellet sebagai solusi dari masalah energi bahan bakar gas yang relatif mahal dan tidak tepat sasaran karena seharusnya gas elpiji $6 \mathrm{~kg}$ hanya diperuntukkan warga miskin bukan IKM. Masalah energi kayu bakar yang memiliki kelemahan pada proses penyimpanan dan pemeliharaan serta kualitas kayu bakar yang terkadang masih basah sehingga mempengaruhi waktu dan kualitas pemasakkan air kelapa pada produk nata de coco. Simulasi penggunaan kompor wood pellet sekaligus dijadikan kegiatan sosialisasi keamanan penggunaan kompor wood pellet pada pengolahan makanan. Asap yang dihasilkan oleh kompor wood pellet lebih sedikit seperti yang ditunjukkan pada Gambar 2. Residu atau sisa pembakaran wood pellet juga lebih sedikit sehingga aman dan tidak mempengaruhi kualitas makanan terutama pada IKM nata de coco. Panas yang dihasilkan cukup tinggi dan bisa diatur temperatur suhunya sehingga proses pemasakan air kelapa sebagai bahan baku nata de coco dapat lebih maksimal. Permintaan pelet kayu industri tahu dan tempe dalam satu tahun sebesar 40.422 ton (Sylviani \& Suryandari, 2013). Keterangan ini membuktikan bahwa wood pellet sudah diakui baik bagi produksi industri olahan makanan.

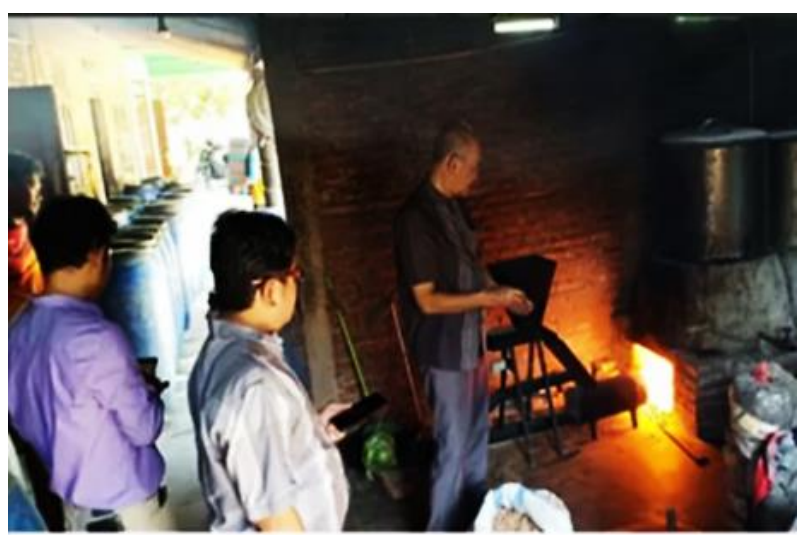

Gambar 2. Introduksi kompor wood pellet 
Simulasi penggunaan kompor wood pellet dilakukan pada lokasi produksi IKM nata de coco. Kompor wood pellet tersebut dapat diatur tingkat temperaturnya sehingga bisa mempermudah proses produksi IKM. IKM diberi penjelasan oleh ahli teknik mesin bernama Doni Eko Mardono bekerjasama dengan tim pengusul. Program pengabdian masyarakat yang terdiri dari dosen dan mahasiswa UMS melakukan pendampingan kepada mitra IKM mengenai kelayakan energi biomassa wood pellet sebagai alternatif pengganti kayu bakar dan gas elpiji. Program ini berkerjasama dengan Ristekdikti, Pemerintah Kabupaten Sragen dan produsen wood pellet Sragen. Capaian kegiatan pengabdian tersebut disajikan pada Tabel I berikut.

Tabel I. Capaian luaran pengabdian masyarakat

\begin{tabular}{ll}
\hline \multicolumn{1}{c}{ Program } & \multicolumn{1}{c}{ Capaian } \\
\hline Sosialisasi tentang energi & Sudah terlaksana \\
biomassa wood pellet & dan terdapat \\
sebagai bahan bakar & peningkatan \\
alternatif selain kayu dan & pemahaman \\
gas elpiji & energi biomassa \\
& wood pellet \\
Introduksi kompor wood & Kedua mitra telah \\
pellet & memiliki kompor \\
& wood pellet \\
Pendampingan & Mitra paham \\
operasional kompor wood & operasional \\
pellet & kompor wood pellet \\
\hline
\end{tabular}

\section{KESIMPULAN}

Permasalahan keterbatasan bahan bakar kayu dan elpiji dapat teratasi dengan penggunaan energy bahan bakar alternatif terbuat dari wood pellet. Wood pellet yang terbuat dari limbah gergaji dari usaha mebel menjadi alasan yang kuat dalam mendukung zero wasted production. Penggunaan kompor wood pellet aman bagi IKM olahan makanan karena tingkat residu atau asap yang relatif sedikit sehingga tidak mempengaruhi rasa makanan. Dari sisi produksi kompor wood pellet yang dapat diatur tingkat temperaturnya dapat memperlancar proses perebusan air kelapa pada IKM nata de coco.

\section{UCAPAN TERIMA KASIH}

Terima kasih kepada tim pelaksana pengabdian masyarakat UMS (dosen dan mahasiswa), ahli teknik mesin, Ristekdikti Tahun Pendanaan 2019, LPPM UMS, Pemerintah Kabupaten Sragen, Produsen Wood Pellet Sragen, dan mitra IKM yang telah memberikan dukungan dan berpartisipasi dalam kegiatan pengabdian yang dilakukan.

\section{REFERENSI}

Arhamsyah, A. 2010. Pemanfaatan Biomassa Kayu sebagai Sumber Energi Terbarukan. Jurnal Riset Industri Hasil Hutan. 2(1):42-48. http://dx.doi.org/10.24111/jrihh.v2i1.914

Ariyanti, M., Purwanto, P., Suherman, S. 2014. Analisis Penerapan Produksi Bersih Menuju Industri Nata De Coco Ramah Lingkungan. Jurnal Riset Teknologi Pencegahan Pencemaran Industri. 5(2):45-50.

http://dx.doi.org/10.21771/jrtppi.2014.v5.no 2.p45\%20-\%2050

Arsad, E. 2014. Sifat Fisik dan Kimia Wood Pellet dari Limbah Industri Perkayuan sebagai Sumber Energi Alternatif. Jurnal Riset Industri Hasil Hutan. 6(1):1-8. http://dx.doi.org/10.24111/jrihh.v6i1.1219

Hendra, D. 2012. Rekayasa Pembuatan Mesin Pelet Kayu dan Pengujian Hasilnya. Jurnal Penelitian Hasil Hutan. 30(2):144-154. https://doi.org/10.20886/jphh.2012.30.2.144154

Hieu, V.M., Rasovska, I. 2017. Developing Cultural Tourism Upon Stakeholders' Perceptions Toward Sustainable Tourism Development in Phu Quoc Island, Vietnam. Research and Science Today. 2(14):71-86.

Iriyanto, S., Winaryati, E., Aminah, S. 2015. Ipteks bagi Masyarakat (IbM) Home Industri Nata De Coco (Sari Kelapa). Value Added: Majalah Ekonomi dan Bisnis. 11(1):1-9.

Nurdyansyah, F., Widyastuti, D.A. 2017. Pengolahan Limbah Air Kelapa Menjadi Nata De Coco oleh Ibu Kelompok Tani di Kabupaten Kudus. 
Jurnal Kewirausahaan dan Bisnis. 21(11):22-30. https://doi.org/10.20961/jkb.v21i11.20900

Sidabutar, V.T.P. 2018. Kajian Peningkatan Potensi Ekspor Pelet Kayu Indonesia sebagai Sumber Energi Biomassa yang Terbarukan. Jurnal Ilmu Kehutanan. 12(1):99-116. https://doi.org/10.22146/jik.34125

Simangunsong, B.C.H., Wilma, K.A., Manurung, E.G.T., Sitanggang, V.J., Tambunan, A.H. 2017. Analisis Biaya Produksi Pelet Kayu. Jurnal Ilmu dan Teknologi Kayu Tropis. 15(1):48-57.

Syamsudin, S., Isa, M., Mangifera, L., Nurhayati, S.F. 2019. Studi Kelayakan Penggunaan Bahan Bakar Wood Pellet pada IKM Nata de Coco di Kabupaten Sragen. In Prosiding Seminar Bisnis Magister Manajemen (SAMBIS) 2019. Surakarta: Universitas Muhammadiyah Surakarta.

Sylviani, S., Suryandari, E.Y. 2013. Potensi Pengembangan Industri Pelet Kayu sebagai Bahan Bakar Terbarukan Studi Kasus di Kabupaten Wonosobo. Jurnal Penelitian Sosial dan Ekonomi Kehutanan. 10(4):235-246. https://doi.org/10.20886/jpsek.2013.10.4.235 $-246$

Sylviani, S., Dwiprabowo, H., Suryandari, E.Y. 2013. Analisis Biaya Penggunaan Berbagai Energi Biomassa untuk IKM (Studi Kasus di Kabupaten Wonosobo). Jurnal Penelitian Sosial dan Ekonomi Kehutanan. 10(1):48-60. https://doi.org/10.20886/jsek.2013.10.1.48-60 